MACHADO, J.C. e GENARO, G. Influence of feeding stimulus on exploratory behaviour of captive-housed domestic cats, Felis silvestris catus. PUBVET, Londrina, V. 7, N. 25, Ed. 248, Art. 1642, Suplemento 1, 2013.

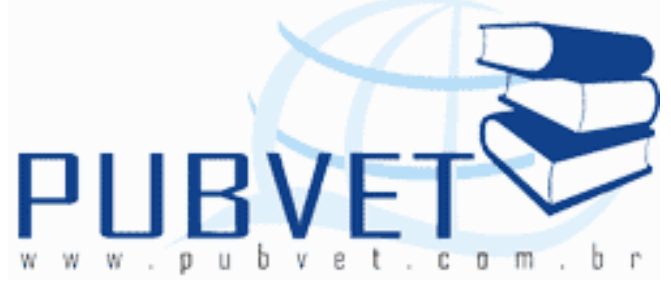

PUBVET, Publicações em Medicina Veterinária e Zootecnia.

\title{
Influence of feeding stimulus on exploratory behaviour of captive- housed domestic cats, Felis silvestris catus
}

\section{Juliana Clemente Machado1*, Gelson Genaro²}

1 Mestre em Comportamento e Biologia Animal - Universidade Federal de Juiz de Fora (UFJF) - Juiz de Fora - MG. Doutoranda do Programa de Pós-graduação em Bioética, ética aplicada e saúde coletiva (Associação ampla entre UFRJ, UERJ, UFF e Fiocruz) - PPGBIOS - Rio de Janeiro - RJ. *juliajoe@terra.com.br 2 Professor Doutor do Programa de Pós Graduação em Ciências Biológicas Mestrado em Comportamento e Biologia Animal - Universidade Federal de Juiz de Fora (UFJF) - Juiz de Fora - MG

\footnotetext{
Abstract

Many proposals for environmental enrichment are planned prioritizing the changes in feeding conditions of animals. This occurs because of the richness of sensory properties of food that motivates not only feeding behaviour and foraging as well as exploration. Exploratory behaviour has been considered as one of the possible indicators of animal welfare. However, in the specific case of domestic cats, the knowledge related to this behaviour is still incipient. Since cats are primary predators, it is expected that a food stimulus favors exploratory behaviour exhibition. Thus, the present study aimed to evaluate the effects of a food stimulus, in exploratory behaviour of captive-housed domestic cats. It was used a piece of meat hanging from a rope in the center
} 
MACHADO, J.C. e GENARO, G. Influence of feeding stimulus on exploratory behaviour of captive-housed domestic cats, Felis silvestris catus. PUBVET, Londrina, V. 7, N. 25, Ed. 248, Art. 1642, Suplemento 1, 2013.

of the room where 42 adult cats lived together, and from this enrichment, behavioural observations were made. The results suggest that in the presence of the stimulus, not all animals exhibited exploratory behaviour, which is possible related to individual differences in the behaviour of cats. It was noted the possession of food resource by a few individuals, probably due to the dominance hierarchy of the social group. In conclusion, this study provides new information about the exploratory behaviour of domestic cats, contributing to the studies on environmental enrichment and welfare of these animals.

Keywords: Environmental enrichment; felids; exploratory behaviour; food; animal welfare.

\section{Influência de um estímulo alimentar no comportamento exploratório de gatos domésticos, Felis silvestris catus em cativeiro}

\section{Resumo}

Grande parte das propostas de enriquecimento ambiental tem sido planejada priorizando as modificações nas condições de alimentação dos animais. Isto ocorre devido à riqueza de propriedades sensoriais do recurso alimentar que motiva não só o comportamento de alimentação e forrageio como também a exploração. O comportamento exploratório tem sido considerado como um dos possíveis indicadores de bem-estar animal. Todavia, no caso específico dos gatos domésticos os conhecimentos relacionados com este comportamento ainda são incipientes. Já que gatos são predadores primários, é esperado que um estímulo alimentar favoreça a exibição da exploração. Assim, o presente estudo objetivou avaliar os efeitos de um estímulo alimentar na exibição de comportamento exploratório dos gatos domésticos. Utilizou-se um pedaço de carne pendurado por uma corda no centro do recinto onde viviam 42 gatos domésticos adultos e a partir deste enriquecimento, observações comportamentais foram realizadas. Os resultados sugerem que na presença do referido estímulo nem todos os animais exibiram comportamento exploratório, o que se relaciona com diferenças individuais no comportamento destes 
MACHADO, J.C. e GENARO, G. Influence of feeding stimulus on exploratory behaviour of captive-housed domestic cats, Felis silvestris catus. PUBVET, Londrina, V. 7, N. 25, Ed. 248, Art. 1642, Suplemento 1, 2013.

felinos. Também foi observada a posse do recurso alimentar por apenas alguns indivíduos, provavelmente devido à hierarquia de dominância social do grupo. Em conclusão, este estudo oferece novas informações a respeito do comportamento exploratório de gatos domésticos, contribuindo com os estudos voltados para o enriquecimento ambiental e o bem-estar destes animais.

Palavras-chave: enriquecimento ambiental; felinos; comportamento exploratório; alimentos; bem-estar animal.

\section{Introduction}

Exploratory behaviour is defined as a group of standard physical actions directed towards an unfamiliar or little-known object or environment (Berlyne, 1966). This behaviour aids in the collection of information (Hughes, 1997) and allows individuals to optimize future reactions to similar events (Blanchard and Cañamero, 2006). Berlyne (1996) defends that curiosity motivates the investigation of novel stimuli and encourages exploration. So, in captivity, a lack of novelty will limit exploratory opportunities, and this may trigger inactivity and abnormal behaviour, which is detrimental to animal welfare (Hughes, 1997). Therefore, environmental enrichment techniques should be employed to promote natural behaviour, including exploration.

Exploratory behaviour is fundamental in the felid behavioural repertoire, because, by gathering information on its environment, an animal gains more control over its situation. The relationship between animal welfare and exploration was demonstrated in studies that noted reduced exploratory behaviour in stressful situations (Carlstead et al., 1993). Under stressful conditions, cats tend to exhibit hiding behaviour or become inactive, and exploratory behaviour diminished (Rochlitz, 2002). Studies on environmental enrichment regarding zoo-housed wild felids, have used exploration as one of the main indicators of animal welfare (Carlstead et al., 1993; Shepherdson et al., 1998). However, we must improve our understanding of exploratory behaviour to be able to use it appropriately as a welfare indicator. Although we have a relatively full understanding of exploratory behaviour in rodents and 
MACHADO, J.C. e GENARO, G. Influence of feeding stimulus on exploratory behaviour of captive-housed domestic cats, Felis silvestris catus. PUBVET, Londrina, V. 7, N. 25, Ed. 248, Art. 1642, Suplemento 1, 2013.

primates, our understanding in felids remains incomplete (Machado and Genaro, 2010).

Because they are predators, felids exhibit more neophilic than neophobic exploratory responses, (Tilson and Seal, 1987). In domestic cats, exploratory behaviour is characterized by visual perception of the object, approximation, sniffing, and/or touching the object, and slow movements around the object (West, 1977).

Few studies have evaluated the influence feeding stimulus in the exploratory behaviour of felids in captivity (Shepherdson et al., 1993; Mcphee, 2002; Wells and Egli, 2004). Stimuli related to prey and hunting behaviours are likely to trigger a significant part of the behavioural repertoire of cats since they are predators.

Food enrichment (fish) showed considerable effects on behaviour in the fishing cat (Prionailurus viverrinus) (Shepherdson et al., 1993). Animals showed reductions in urinary cortisol levels, stereotyped pacing, and sleeping time and increased exploratory behaviour.

The present study aimed to extend our understanding of the influence of feeding stimulation in exploratory activity in captive-housed domestic cats. The results may have implications for increasing cat welfare in shelters. Our general hypothesis was that feeding stimulus would promote exploratory behaviour. However, we hypothesized an individual variation in the degree of interaction with the food. Importantly, some studies have demonstrated that factors like social hierarchy (Durr and Smith, 1997), sex (Hughes, 1968; Gray and Buffery, 1971) and temperament (Powell and Svoke, 2008; Ellis, 2009) could influence the exploratory behaviour of cats and other species. Thus, we considered these aspects in the present study. 
MACHADO, J.C. e GENARO, G. Influence of feeding stimulus on exploratory behaviour of captive-housed domestic cats, Felis silvestris catus. PUBVET, Londrina, V. 7, N. 25, Ed. 248, Art. 1642, Suplemento 1, 2013.

\section{Materials and Methods}

\section{Animals and study location}

This experiment included 42 (19 male and 23 female) neutered, adult, vaccinated cats of mixed-breed that were identified according to fur and eye color. Most were abandoned when they were young, and found their way to a private animal shelter, where they were treated for endoparasites and ectoparasites and housed together from when they were kittens. The private animal shelter was located in Ribeirão Preto city, São Paulo state, Brazil. It included a total fenced-in area of $1.250 \mathrm{~m}^{2}$ for the animals, and it met the requirements of the Animal Welfare Institute (Rochlitz, 2002). It included an open-air structure, with a cement floor and a roof that covered approximately $1 / 3$ of the floor for protection from environmental elements, like rain and wind. It also included shelves at different heights, hiding places, and resting boxes and trunks. The study was conducted in a noncovered area used by the cats. A veterinary doctor was responsible for the sanitary control of the premises. The area was cleaned on a daily basis, and animals had free access to cat food (pellets) and fresh water located at multiple points in the enclosure. During experiment, the regular food and water routine was not modified.

\section{Experimental design}

Based on previous studies, we presented meat to the animals by tying $300 \mathrm{~g}$ of raw beef to the end of a nylon rope and hanging it $30 \mathrm{~cm}$ above ground level, allowing cats to grab and eat the meat. The study arena consisted of a circular area, $2 \mathrm{~m}$ in diameter, delineated by a circle that had been drawn on the floor with non-toxic, permanent paint in the original shelter (not produced for the study). A $1-\mathrm{m}^{2}$ area was drawn in the center of the circular arena to delimit an area closer to the stimulus. Thus, the test arena was part of the cats' normal home range, not separate from their common space. Cats were allowed to explore voluntarily, after the researcher had 
MACHADO, J.C. e GENARO, G. Influence of feeding stimulus on exploratory behaviour of captive-housed domestic cats, Felis silvestris catus. PUBVET, Londrina, V. 7, N. 25, Ed. 248, Art. 1642, Suplemento 1, 2013.

hung the food over the arena and left the study area. Video recordings were initiated at $5 \mathrm{~s}$ after the researcher left the study area with a Samsung L100 digital camera attached to the side of the shelter. Videos were recorded between $16: 00 \mathrm{~h}$ and 17:00 $\mathrm{h}$ at a resolution of 8.2 megapixels. An average of 40 min elapsed before the cats consumed the hanging meat; thus, this 40-min period was considered the study observation time. One observation period was conducted each day for 7 days.

\section{Observations}

Video recordings were analyzed by the experimenter after all procedures with a scan sampling method (Altmann, 1974). This method collected video frames every $30 \mathrm{~s}$, resulting in 80 scans/day. The observation parameters were expressed as the number of animals that performed the behaviour. The following behavioural parameters were measured: total number of cats located within the arena, number of cats located inside the square area, number of cats handling the food, looking at the food, engaged in allogrooming, engaged in self-grooming, and present in the arena, but do not exhibiting any of the target behaviours (i.e., 'looking at another point') (Table 1).

Observations were recorded on a spreadsheet, where rows corresponded to the behavioural parameters and columns corresponded to each of the 80 video scans. Each cell recorded the number of cats that displayed the behaviour in one scan. We used 7 spreadsheets, one for each day.

Exploratory behaviour was defined as the presence of an animal in the study arena (Bergman and Kitchen, 2009), because presence in the area represented neophilia. Table 1, constructed according to Mota and Reis (2009) and Ellis and Wells (2010), lists the types of behaviour that we observed during the study. Despite the fact that allogrooming and self-grooming were not considered exploratory behaviours, they were analyzed, because domestic cats may perform them after contact with food (Beaver, 1992). 
MACHADO, J.C. e GENARO, G. Influence of feeding stimulus on exploratory behaviour of captive-housed domestic cats, Felis silvestris catus. PUBVET, Londrina, V. 7, N. 25, Ed. 248, Art. 1642, Suplemento 1, 2013.

Table 1. Descriptions of cat behaviours observed during the feeding stimulation ( $\mathrm{N}=42$ cats)

\begin{tabular}{|c|c|}
\hline Behaviour & Description \\
\hline Exploratory & $\begin{array}{l}\text { Cat is present in the study arena and exhibit one of } \\
\text { the following types of behaviour: looking at food, } \\
\text { handling food, looking at another point; self-grooming, } \\
\text { and allogrooming. }\end{array}$ \\
\hline Looking at food & $\begin{array}{l}\text { Cat directs the head and eyes toward the food, while } \\
\text { pacing or standing. }\end{array}$ \\
\hline Handling food & Cat uses the mouth or the limbs to handle the food. \\
\hline Self-grooming & $\begin{array}{l}\text { Although self-grooming is not an exploratory } \\
\text { behaviour, it is exhibited in the study arena, near the } \\
\text { food stimulus. The cat uses the tongue or the limbs for } \\
\text { self-grooming on any part of its own body. }\end{array}$ \\
\hline Allogrooming & $\begin{array}{l}\text { Although allogrooming is not an exploratory behaviour, } \\
\text { it is exhibited in the study arena, near the food } \\
\text { stimulus The animal rubs its tongue on any part of the } \\
\text { body of a companion. The groomed animal does not } \\
\text { behave agonistically. }\end{array}$ \\
\hline $\begin{array}{l}\text { Looking at } \\
\text { another point }\end{array}$ & $\begin{array}{l}\text { Although the cat is present in the study arena, it is not } \\
\text { positioned near the stimulus and do not handle or look } \\
\text { at it. No other behaviour is noted, including } \\
\text { allogrooming and self-grooming. The animal is present } \\
\text { in the area, but is not directing attention to the } \\
\text { stimulus offered. }\end{array}$ \\
\hline Nonexploratory & $\begin{array}{l}\text { All the cats that are not present in the study arena are } \\
\text { disregarded in the analysis, as proposed by Bergman } \\
\text { and Kitchen (2009). }\end{array}$ \\
\hline
\end{tabular}


MACHADO, J.C. e GENARO, G. Influence of feeding stimulus on exploratory behaviour of captive-housed domestic cats, Felis silvestris catus. PUBVET, Londrina, V. 7, N. 25, Ed. 248, Art. 1642, Suplemento 1, 2013.

This research was approved by the Research Ethics Committee of Centro Universitário Barão de Mauá de Ribeirão Preto, São Paulo, Brazil; registered under number 130/2009.

\section{Statistical analysis}

For statistical analyses, we counted the number of animals that performed each behaviour (Table 1 ) in the 80 video scans for each day. We observed which animal exhibited each behaviour and the frequency. Data are presented as mean $[\bar{x}] \pm$ standard error. Non-parametric evaluations of untreated data were performed using Friedman $(F r)$ and Wilcoxon $(Z)$ tests at a $5 \%$ level of significance. Analyses were performed using Biostat 5.0 and Microsoft $®$ Office Excel 2003.

\section{Results}

Based on the total number of animals in the enclosure $(N=42)$, between 9.67 and $21.87 \%$ of animals exhibited exploratory behaviour. The number of exploring animals $(\bar{x}=7.38 \pm 0.07)$ changed during the experiment $(\mathrm{Fr}=$ $211.573 ; p<0.0001)$. Fewer animals exhibited exploratory behaviour on first day than on the last ( 7 th $)$ day $(Z=4.758 ; p<0.0001)$.

The number of animals that exhibited 'handling food' ( $\bar{x}=1.46 \pm 0.02)$ also varied during the experiment $(F r=120.367 ; p<0.0001)$. Fewer animals exhibited this behaviour on the first day than on the last day $(Z=5.214 ; p<$ 0.0001) (Fig. 1).

We observed that the same individuals dominated food ownership. This was determined by combining the parameter 'handling food' with the identity of the animals positioned in the central area of the study arena. Five cats took turns in handling food, but two (a male and a female) dominated most of the time. Agonistic behaviour was not detected. 
MACHADO, J.C. e GENARO, G. Influence of feeding stimulus on exploratory behaviour of captive-housed domestic cats, Felis silvestris catus. PUBVET, Londrina, V. 7, N. 25, Ed. 248, Art. 1642, Suplemento 1, 2013.

The number of animals that exhibited 'looking at another point' changed $(\bar{x}=2.97 \pm 0.06)(F r=82.688 ; p<0.0001)$ during the experiment. The number was lower on day 1 than on day $7(Z=3.943 ; p<0.0001)$ (Fig. 1$)$.

A small number of animals exhibited 'looking at food' $(\bar{x}=2.54 \pm 0.07$; Fig. 1). This number varied during the experiment $(F r=89.000 ; p<0.0001)$, with a lower number exhibiting this behaviour on day 1 than on day 7 ( $Z=5$. 302; $p<0.0001)$.

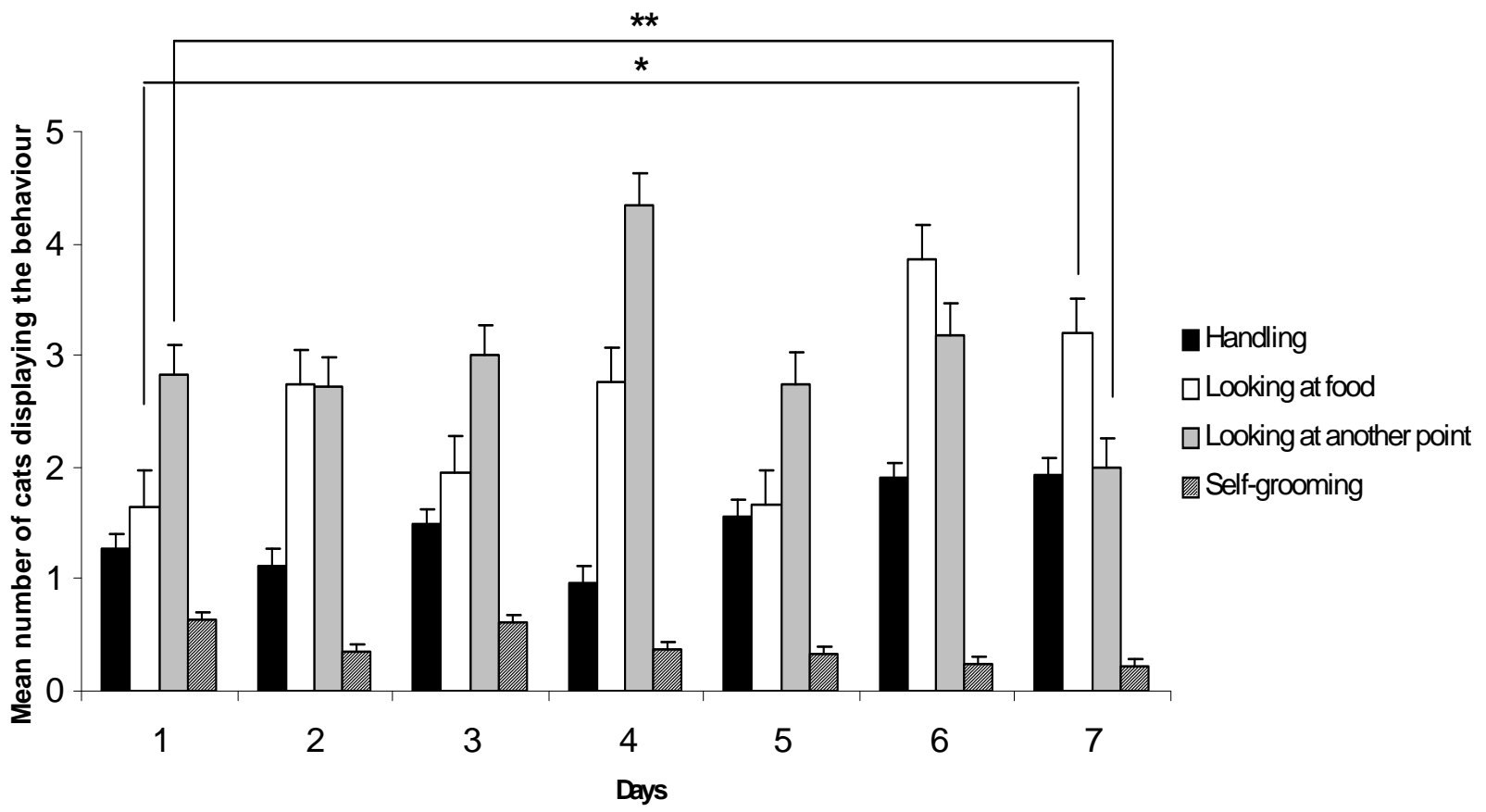

Fig. 1 Exploratory behaviour during feeding stimulation: The means \pm standard errors are shown for the number of cats that responded to the food stimulus by handling, looking at the food, looking at another point, and selfgrooming. The means are based on the average number of animals present in the study arena each day. (Friedman and Wilcoxon tests; Biostat 5.0, Brazil, and Microsoft $\AA$ Office Excel 2003, USA. The $p$ value $<0.05$ was regarded as significant and marked as $*$ for significant increase in the number of animals displaying the behaviour and $* *$ for significant reduction in the number of animals displaying the behaviour). 
MACHADO, J.C. e GENARO, G. Influence of feeding stimulus on exploratory behaviour of captive-housed domestic cats, Felis silvestris catus. PUBVET, Londrina, V. 7, N. 25, Ed. 248, Art. 1642, Suplemento 1, 2013.

Self-grooming was recorded for very few individuals $(\bar{x}=0.39 \pm 0.02)$, but it also varied during the experiment $(F r=18.000 ; \mathrm{P}=0.0049)$. Day-today comparisons revealed some differences, but comparison between days 1 and $7(Z=3.428 ; P=0.0006)$ showed a decline in this behaviour over time (Fig. 1), although the number of cats present in the arena between days 1 and 7 has increased significantly $(Z=4.758 ; p<0.0001)$. Allogrooming was absent.

Among the behaviours recorded, 'looking at another point' was the most statistically significant, until the fifth day. On the sixth day, there was no difference between 'looking at another point' and 'looking at food' ( $Z=1$. 713, $p=0.086)$. On the seventh day, 'looking at food' was more frequent than the other types of behaviour (Fig. 1).

\section{Discussion}

The present study aimed to evaluate the effects of feeding stimulus on exploratory behaviour in captive-housed domestic cats. We showed that a small number of cats exhibited exploratory behaviour, which suggested dominance of item ownership. Five cats appeared to take alternate ownership during the experiment days. Two cats dominated the food in alternation, or they shared with each other. The other three cats did not dispute the item, but exhibited 'looking at food', 'looking at another point', or 'self-grooming'. The latter three cats only explored when the two dominant animals had abandoned the food. Thus, we saw two rankings of interaction: the first consisted of the two dominant cats, and the second included the three less-dominant cats.

For cats, hierarchy depends on context (Durr and Smith, 1997). According to Crowell-Davis et al. (1997), social hierarchy is a ritualized, adaptive relationship that minimizes conflicts within the group. Therefore, cats do not maintain a hierarchy via aggressive behaviour, but possibly via signals of social status. Although the present study did not conduct tests of dominance, we hypothesized that there was an established social hierarchy in the group studied, because these same cats had lived together from 
MACHADO, J.C. e GENARO, G. Influence of feeding stimulus on exploratory behaviour of captive-housed domestic cats, Felis silvestris catus. PUBVET, Londrina, V. 7, N. 25, Ed. 248, Art. 1642, Suplemento 1, 2013.

kittenhood. Thus, the dominance held over the resource pointed to which cats were the most dominant in the social hierarchy since socially dominant cats use to have priority of access to preferred recourses over subordinate cats. However, this must be confirmed in future studies with specific tests measuring, for example, the access to daily food and body positions in relation to another cat such as ear and tail (Crowell-Davis et al., 2004).

Previous studies on different kinds of captive-housed animals have demonstrated individual preferences during feeding enrichment (Bradshaw et al., 2000; Morimura and Ueno, 1999). Powell and Svoke (2008) also stated that feeding enrichment can allow detection of individual preferences. Ellis (2009) has articulated that cat temperament should be considered during the design of environmental enrichment; the experimenter should verify which techniques are best for active, passive, frustrated, and anxious animals. Our proposed feeding enrichment appeared to be appropriate for active animals, which tend to have a low level of neophobia.

During most of the study period, the number of animals exhibiting 'looking at another point' was higher than the number of animals that displayed any other type of behaviour. This behaviour does not appear to be an active form of exploration; however, in this study, an animal's presence in the test arena was taken as evidence of motivation for exploratory behaviour compared to an absence from the arena. Cats that remained absent from the arena might have had higher levels of neophobia (Hughes, 1997), passive or anxious temperaments (Ellis, 2009), or low hierarchic positions (Durr and Smith, 1997).

We did not detect allogrooming, probably because the context did not promote this behaviour. According to Van den Bos (1998), allogrooming redirects aggressive tendencies. We did not observe any potential aggressive behaviour that might have prompted allogrooming. According to another hypothesis, allogrooming can maintain positive social relations between pairs of individuals (Van den Bos 1998). We did not expect this to occur in the present study, because the animals were focused on a non-social situation. 
MACHADO, J.C. e GENARO, G. Influence of feeding stimulus on exploratory behaviour of captive-housed domestic cats, Felis silvestris catus. PUBVET, Londrina, V. 7, N. 25, Ed. 248, Art. 1642, Suplemento 1, 2013.

Self-grooming was exhibited by fewer cats. This behaviour removes old fur, regulates temperature, spreads body scent, controls ectoparasites (Tabor, 2003), and relieves tension (Beaver, 1992). Animal attention to other activities could explain the lack of body maintenance behaviour. Nevertheless, the few animals that showed self-grooming may have done so in order to alleviate the tension of waiting for an opportunity for exploration. Animals that had explored may have self-groomed to remove meat fragments that remained on their fur.

Based on these observations, it could be suggested that this technique was not particularly suitable for promoting exploration or a big group of captive cats, because very few animals demonstrated this behaviour. However, we believe that the exploratory behavior was stimulated for at least those few animals. We recommend feeding enrichment as a technique that can promote exploration, but we suggest that several identical feeding stimuli should be placed concurrently, in randomly distributed locations, as suggested previously (Ellis and Wells, 2010). This would offer more exploratory opportunities for a larger number of individuals, and it may reduce the effects of hierarchy and individual differences in temperament.

In conclusion, we would like to emphasize that the number of cats housed in confined spaces has risen as a result of many changes in society, including increased apartment living, reduced access to outdoors, and increased numbers of stray cats living in shelters. Space restriction is typically accompanied by lower environmental quality, with consequent loss of the behavioural repertoire of felids. Cats tend to become inactive under stressful conditions, and reduce their exploratory behaviour. This study demonstrated that feeding stimulus, enhanced the exploratory behaviour of some captivehoused cats. However, the influences of social hierarchy and personality should be further investigated. Our experiment showed that food enrichment may be useful for detecting exploratory behaviour, as suggested by Powell and Svoke (2008). We also showed that cat temperament and social hierarchy may interfere with exploratory motivation, which corroborated the findings of Ellis and Wells (2010). Our results reinforced the findings of other authors and 
MACHADO, J.C. e GENARO, G. Influence of feeding stimulus on exploratory behaviour of captive-housed domestic cats, Felis silvestris catus. PUBVET, Londrina, V. 7, N. 25, Ed. 248, Art. 1642, Suplemento 1, 2013.

contributed with new data to the field. These data are expected to increase the understanding of how exploratory behaviour relates to the welfare of domestic cats in captivity. We have also pointed to the possible influence of dominance hierarchy in exploratory behaviour; therefore, we encourage further research to increase the understanding of this relationship.

\section{Acknowledgment}

We would like to thank the owner of the private cattery, the animal caretakers, the Master's Program in Animal Behaviour at the Federal University of Juiz de Fora (UFJF, Minas Gerais, Brazil), and the research funding agency in Brazil, CAPES (Coordenação de Aperfeiçoamento de Pessoal de Nível Superior [Coordination for the Improvement of Higher Education Personnel]).

\section{References}

Altmann, J. 1974. Observational Study of Behavior: Sampling Methods. Behaviour. 49, 227267.

Beaver, B.V. 1992. Feline Behavior: A guide for veterinarians. Saunders.

Bergman, T.J. and Kitchen, D.M. 2009. Comparing responses to novel objects in wild baboons (Papio ursinus) and geladas (Theropithecus gelada). Anim. Cogn. 12, 63-73.

Berlyne, D.E. 1966. Curiosity and exploration. Science. 53, 25-33.

Blanchard, A. and Cañamero, L. 2006. Modulation of Exploratory Behavior for Adaptation to the Context. In Proceedings of the AISB'06 Symposium on Biologically Inspired Robotic. AISB Press, pp: 131-137

Bradshaw, J.W,S., Healey, L.M., Thorne, C.J., McDonald, D.W. and Arden-Clark,C. 2000. Differences in food preferences between individuals and populations of domestic cats (Felis silvestris catus). Appl. Anim. Behav. Sci. 68, 257-268.

Carlstead, K., Brown, J.L. and Seidensticker, J. 1993. Behavioral and adrenocortical responses to environmental changes in leopard cats (Felis bengalensis). Zoo. Biol. 12, 321-331.

Crowell-Davis, S.L., Barry, K. and Wolfe, R. 1997. Social behavior and aggressive problems of cats. Vet. Clin. North. Am. Small Anim. Pract. 27, 549-568.

Crowell-Davis, S.L., Curtis, T.M. and Knowles, R.J. 2004. Social organization in the cat: A modern understanding. J. Feline Med. Surg. 6, 19-28.

Durr, R. and Smith, C. 1997. Individual differences and their relation to social structure in domestic cats. J. Comp. Psychol. 111, 412-418.

Ellis, S.L.H. 2009. Environmental enrichment: Practical strategies for improving feline welfare. J. Feline. Med. Surg. 11, 901-912. 
Ellis, S.L.H. and Wells, D.L. 2010. The influence of olfactory stimulation on the behaviour of cats housed in a rescue shelter. Appl. Anim. Behav. Sci. 123, 56-62.

Gray, J.A. and Buffery, A.W.H. 1971. Sex differences in emotional and cognitive behaviour in mammals including man: Adaptive and neural bases. Acta Psychol. 35, 89-111.

Hughes, R.N. 1997. Intrinsic exploration in animals: motives and measurement. Behav. Processes. 41, 213-226.

Machado, J.C and Genaro, G. 2010. Comportamento exploratório em gatos domésticos (Felis silvestris catus Linnaeus, 1758): uma revisão. Arch. Vet. Sci. 15,107-117.

Mcphee, E.M. 2002. Intact carcasses as enrichment for large felids: Effects on- and off-exhibit behaviors. Zoo Biol. 21, 37-47.

Morimura, N. and Ueno, Y. 1999. Influences on the feeding behaviour of three mammals in the Maruyama Zoo: bears, elephants and chimpanzees. J. Appl. Anim. Welf. Sci. 2, 169-186.

Mota, M.C. and Reis, N.R. 2009. Elaboração de um catálogo comportamental de gato-do-matopequeno, Leopardus tigrinus (Schreber, 1775) (Carnivora: Felidae) em cativeiro. Biota Neotrop. 9, 165-171.

Powell, D.M. and Svoke, J.T. 2008. Novel Environmental Enrichment may provide a tool for rapid assessment of animal personality: A case study with Giant Pandas (Ailuropoda melanoleuca). J. Appl. Anim. Welf. Sci. 11, 301-318.

Rochlitz, I. 2002. Comfortable Quarters for Cats in Research Institutions. http://www.awionline.org/pubs/cq02/ cq-cats.html. Accessed 8 June 2012.

Shepherdson, D.J., Carlstead, K., Mellen, J.T. and Seidensticker, J. 1993. The influence of food presentation on the behavior of small cats in confined environment. Zoo Biol. 12, 203-216.

Shepherdson, D.J., Mellen, J.D. and Hutchins, M. 1998. Second Nature: Environmental Enrichment for Captive Animals. Smithsonian Institution Press.

Tabor, R. 2003. Understanding cat behavior: the complete feline problem solver. David \& Charles.

Tilson, R.L. and Seal, S.U. 1987. Tigers of the world: the biology, biopolitics, management and conservation. Noyes Publications.

Van den Bos, R. 1998. Post-conflict stress-response in confined group-living cats (Felis silvestris catus). Appl. Anim. Behav. Sci. 59, 323-330.

Wells, D.L. and Egli, J.M. 2004. The influence of olfactory enrichment on the behaviour of black-footed cats, Felis nigripes. Appl. Anim. Behav. Sci. 85, 107-119.

West, M. J. 1977. Exploration and play with objects in domestic kittens. Dev. Psychobiol. 10, 53-57. 